ADAM NADOLNY

Faculty of Architecture Poznan University of Technology

\title{
Image of the city and modern architecture in the Polish feature films of the $1960 s^{\prime *}$
}

\begin{abstract}
Nadolny Adam, Image of the city and modern architecture in the Polish feature films of the 1960s'. „Images” vol. XXII, no. 31. Poznań 2017. Adam Mickiewicz University Press. Pp. 135-144. ISSN 1731-450X. DOI 10.14746/i.2017.31.13.

This article focuses on the inter-dependencies between the film image and architecture. The author has attempted to define what sort of historical background preconditions the film image to gain the status of a source for research on the history of Polish urban planning and post-war architecture, with particular emphasis placed on the 1960s.
\end{abstract}

KEYwORDS: architecture, city, film, film image, space

In the case of Polish architecture, one may observe the phenomenon of a modern town/city as early as during the inter-war period.[1] It was then that numerous concepts on the shaping of the city were conceived on the basis of the then prevailing theory, which maintained that man as an individual living in the town was the most important purpose thereof. A modern city was then to be characterised mainly by extensive spaciousness, the application of the geometric forms of the buildings provided with simple details and greenery completing the urban composition.

The years of World War II were the years when the development of architecture and modern urban planning was hampered in Poland. The post-war period of the reconstruction after the destruction of the war in Poland, in its first stage from 1945 to 1948, without doubt featured attempts to return to the idea of the modern town prevailing in the inter-war period. Unfortunately, due to the political changes in Poland, then under the influence of the Soviet Union, which extended over all of Eastern Europe, the ideas of modernism were, after 1948, replaced with top-down imposed social realism. Adam Kotarbiński defined this period in Polish architecture, quite accurately, saying that "Social realism as a theory would not just negotiate but would also pose demands

* This article makes up part of the research project entitled "Architecture and the town in Polish films of the 1960s and 1970s", stage III, financed with the funds designated by the Ministry of Science and Higher Education for the statutory activities at the Faculty of Architecture at Poznań University of Technology in 2017.

\section{Images} vol. XXII/no. 31 Special Issue Poznań 2017 ISSN 1731-450x
What is a modern city in the history of Polish architecture?
[1] The period from 1918 to 1939 was defined in the history of Polish architecture as one of the period of many changes connected both with the architectural attire of the buildings and with the ideas pertaining to the modern town/city. 
of a structural nature. Generally speaking, its demands would come down to the slogan «architecture [that would be] socialist in contents and national in form»".[2]

This trend in Polish architecture and urban planning showed certain features of the return to historical architecture, where the classical connotations would play a significant formal and spatial role. Classical solutions in the urban planning of the Polish cities of the post-war period were contrary to the ideas propagating modern trends.

This changed after 1956 when, due to the political changes, Polish architecture once again turned towards modernism. Because the reconstruction of many Polish cities and towns after the wartime destruction was still in progress, there was very high demand for new space, both space dedicated to public purposes and that dedicated to more basic functions such as multi-family residential blocks. Such high demand for new flats contributed without doubt to a prompt, increased interest in modernism, the postulates of which included, among others, the 'mass production of houses. Thus, one may observe the return of modernism in the Polish architecture of the 1960s has come into being.

Selection of research material

[2] A. Kotarbiński, O ideowości i ideologii w architek-

turze i urbanistyce, Warszawa, 1985, p. 52.

Research material for the needs of this publication was downloaded from the website featuring Polish films: www.Filmpolski.pl, which is a collection of Polish films produced in the years covered by this research, that is, during the 10-year period from 1960 to 1970 , among other years. In view of the specific nature of the research, we have assumed the following criteria to be met by our research material: full-length Polish cinema feature films made in the aforementioned period in Poland by a Polish director, with Polish being the language of the script. The database of Polish films also includes collections of other types of films such as: short-feature films, television films, television plays, documentaries, cartoons and students' first short films. For the reason of the focus of the author's research, we have further analysed exclusively full-length cinema feature films. The preliminary research intended for the selection of the information collected in the database has shown that, as regards Polish films, the number of films made in respective years is very high. To present the scale of the Polish film production in the period under analysis, that is from 1960 to 1970 , I would like to refer to the following data:

Another stage for the selection of the research material was the selection of cinema feature films meeting the adopted at the beginning criteria from the list of films included in the database of feature films. As I have already mentioned, only Polish films made in Poland and presented in the Polish language were taken into account within the process of detailed selection. The tables below present the selection of cinema feature films made in the period from 1960 to 1970 broken down per genre. It must be stated that from the point of view of the 
Table 1. Number of film productions in the years 1960-1970 drawn up on the basis of the database of Polish films. The total of all the films made in respective years includes the following types of film productions: cinema full-length feature films, television feature films, documentary films, cartoons, students' first short films, television series, television plays. Author's work

\begin{tabular}{|c|c||c|c|}
\hline Year & $\begin{array}{c}\text { Number of film } \\
\text { productions }\end{array}$ & Year & $\begin{array}{c}\text { Number of film } \\
\text { productions }\end{array}$ \\
\hline 1960 & 312 & 1966 & 509 \\
\hline 1961 & 355 & 1967 & 573 \\
\hline 1962 & 353 & 1968 & 601 \\
\hline 1963 & 396 & 1969 & 607 \\
\hline 1964 & 395 & 1970 & 598 \\
\hline 1965 & 523 & Total & $\mathbf{5 2 2 2}$ \\
\hline
\end{tabular}

assumed time period, in our further research we shall exclusively focus on films with plots featuring contemporary times, which include the time period of our analysis. A film director operating within the Polish cultural zone shall constitute another decisive factor.

The specific nature of Polish films made in the 1960 s was to a large extent related to the manner of their production conditioned by the financial support from the government. The films made in the in the period being analysed feature a variety of genres: psychological films, historical films, war films and other films. Each of the images presented would contribute new values to the visual sphere of Polish film industry. Nevertheless, in view of the main directions of research, cinema films have been selected for research after an in-depth selection process.

A modern city/town with its ideas, geometries, forms and functions, was juxtaposed against the city/town traditionally perceived as the city/town with a network of winding streets and squares. Modernism propagated open space, space that is less cosy than that in the historical city. The already mentioned post-war trend of urbanisation of the Polish cities in the 1960 s spread following two ways. On the one hand, the reconstruction process of the historical city centres after the war destruction[3] ended; on the other hand, the suburbs accommodated new concepts of spatial development based on the principles of modernism.

The reconstruction of the historical city centres was intended to recreate the spatial, visual and in a way spiritual values of the urban as the representation of the past and the national heritage. In many instances, the historical, urban structure was supplemented with modern forms, mainly in those parts, where no sufficiently preserved source documents existed. [4]

[3] Warsaw, Poznań, Gdańsk, Szczecin and others.

[4] Historical views, plans, maps, inventory records and other documents.

\section{A modern city and the Polish reality of the 1960 s}


Modernism seen as the recipe for urbanisation of the Polish cities in the post-war period
The second direction of those followed by the urban reconstruction activities were the works marked with a modern character. The new style was applied both in the newly constructed fragments of the 'downtown' development such as the Eastern Wall in Warsaw, $\left.{ }^{5}\right]$ and also in the newly constructed housing estates located outside the 'downtown' area. Numerous housing estates constructed using the large concrete panel technology are the effect of that period in Polish urban planning.

As already stated in my considerations, modernism became a prevailing tendency in the architecture and urban planning implemented in the Polish towns. The factors that contributed to such a state of affairs were primarily technical and technological issues. The application of prefabricated technology as the main method for shaping the building form was to contribute to their faster erection. Yet, this pressure on speed of construction quite often resulted in poor quality and usability problems. Post-war urban planning in Poland was to ensure the highest number of flats for the developing society; on the other hand, the economic problems of the Polish People's Republic[6] effectively hampered the implementation of these ambitious plans.

Another important factor was the ideology, which maintained that a new socialist society can be, or even should be modern. Such ideological modernity translated into the issues of urban planning. The urban planning and modernity were consistent with the official language of the system, which propagated an image of the country spectacularly developing in a number of areas. Once again, I would like to quote Adam Kotarbiński, who summarized the achievements of socialism in this area in the following words "The achievements of urban planning are most clearly visible in large projects made available to the public when completed in the form of important, new architectural and structural facilities with orderly surroundings.[7]"

The urbanisation of Polish cities in the spatial perspective involved an important social aspect. In a way, modernism triggered the emergence of a new society, new representatives of the post-war Poland. Society was fascinated with modernity of the town, with the big difference between a modern town and for instance a village, with the metropolitan atmosphere of the town, its renderings, the play of light and shade in space. Summing up, we could say they were, in a way, fascinated with all these elements, which were also frequently showcased by the film industry of the period.
[5] The architects of the building, located in Warsaw, were: Zbigniew Karpiński, Jan Klewin, Andrzej Kaliszewski, 1962-1969.

[6] Within the framework of the centrally planned economy, which prevailed in Poland in the communist period, all the spheres of economic activity were subjected to the state. Such a central management of the economy led to a number of problems, among others in the construction industry - no sufficient quantities of building materials, interruptions in deliveries, poor quality of materials. All these issues exerted an impact upon the shaping of the post-war image of the construction industry in the Polish People's Republic.

[7] A. Kotarbiński, op.cit., p. 123. 
The dynamics of the urban image are due to its nature and properties. This issue was aptly defined by Jan Jacoby in 1968 in "Kino" magazine. "The key issue of film is its motion in space and time, and elimination of just one of these components deprives the film of its nature". [8] The dynamics of the film image, action shots, sequences and the film set combine smoothly with the idea of a modern town. In its modern space, the dynamics of the people becomes its main asset. If no people are present, irrespective of what space one would create, such a space would be still if devoid of any human presence.

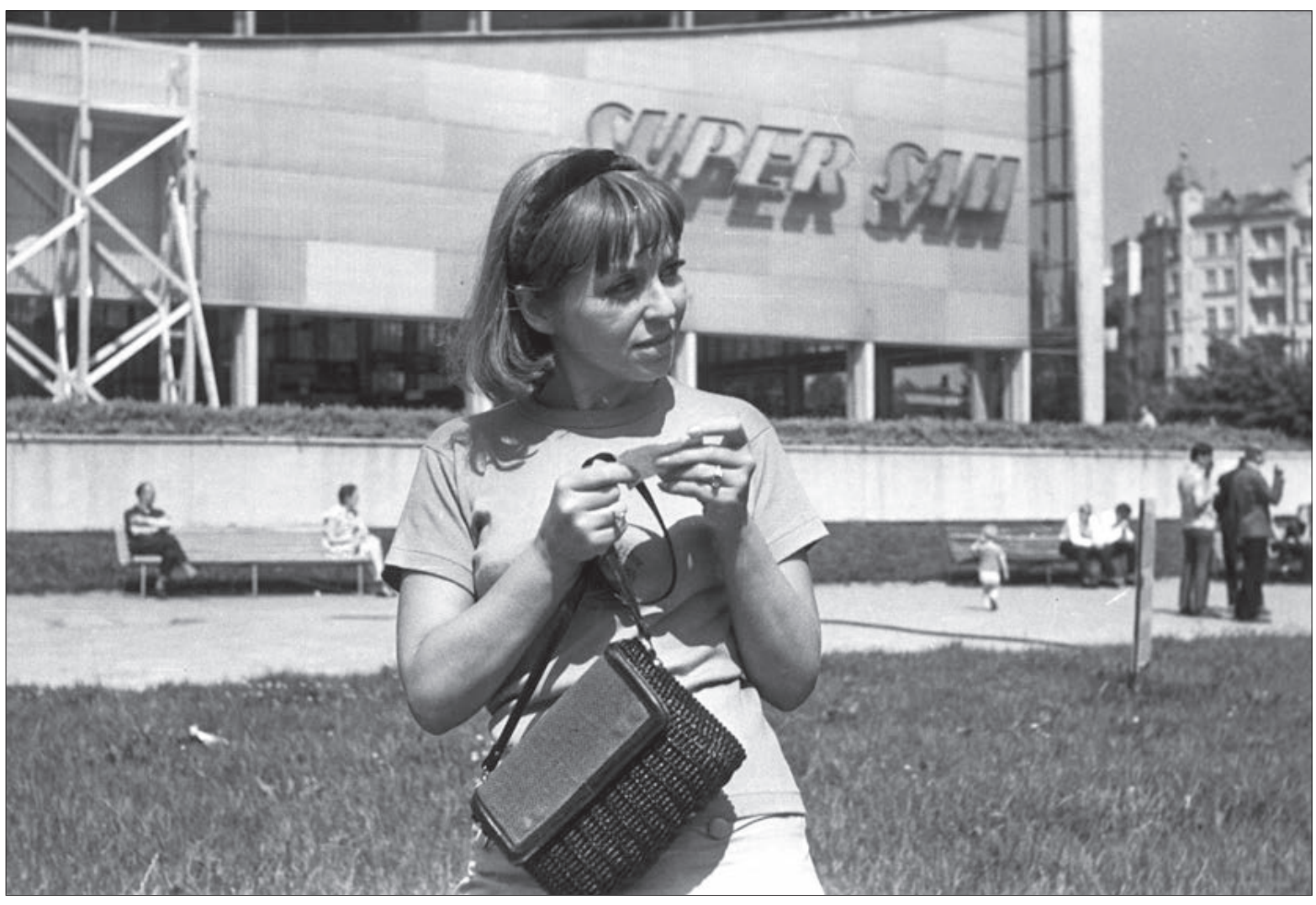

Film is a great recording medium for the changeable dynamics of urban space. What is grasped by the architect in his or her design or concept rendered in a hardcopy or a carbon copy is, in fact, to be of a 3-D nature in space, where respective views form the joint space of the architectural work and interact with the recipient.

The modern town is shown in 1960 os Polish feature films as a certain type of a spatial game played between the user of space and the architect. Such a game was, among others, presented by Jerzy Kawalerowicz in his film Gra [Game] of 1968. The sequences of a modern city presented by the director, based on the example of Warsaw, constitute an interesting story featuring the dynamic expression of a modern town. In this film the modernity of the city is not limited only to a portrait of the [8] J. Jacoby, Film jako cybernetyczny przekaz informacji, "Kino" 1968, no. 3, p. 42.
Film image as the means of recording the dynamics of urban space
Il. 1. Joanna (Kalina Jędrusik), the main character of a film entitled Lekarstwo na miłość [Cure for Love] against the background of the modern building of the Super Sam store in Warsaw, which no longer exists. 1-F-2306-280 
buildings in urban structure. One of the most interesting scenes in the film is the one where the main character, Małgorzata, played by Lucyna Winnicka, looks through the big windows of her architectural study at the panoramic view of a Warsaw street. The scene is accompanied with sequences of the traffic and the crowds of people seen through the extensive glazing of the building façade.

The film also features shots where the camera follows the film characters moving along the streets of Warsaw. The urban views which the camera records are not only images of the idyllic Old Market Square, but also of the centre of a large city, marked with modern buildings and filled with. The dynamic sequences of the film make the image of Warsaw seem surreal and somewhat immaterial.

The reviewer, Jerzy Płażewski, in his "Kino" magazine review of the film 1969 directed by Kawalerowicz, accused the director of changing the point of reference with respect to the characters appearing in the film space in an intentional and almost authoritarian manner. "These are all fragments of lives, let us assume they are true and crucial, nevertheless, they disturb the film's plot, simply observing the creator's/ dictator's whims." [9] In my opinion this voracity of the director, his interest in sequences and dynamics, is the reason why, from the point of view of the history of architecture, he was able to preserve the image of Warsaw in 1968 in the film shots. His city was modern and free from any references to the political situation prevailing at the time and was only to present the space and the manner of its perception by the characters in the film.

A modern city in the feature film as the means of recording past events
Once again, I wish to refer to the words of Jan Jacoby, who so defined the concept of an art film of the late 1960s: "An art film is a creative work that creates a new, probable reality, which is, in fact, made up [by the artist]".[10] Such an approach, from the point of view of the film review, must certainly be the right approach; however, this statement may be interpreted differently in reference to the history of architecture. From the perspective of the time, which changes both the manner of interpretation and the description of an architectural work, such architectural works may be seen as a starting point for a discussion on the meaning of the image captured in the film as part of the ideological context.

Modern architecture of the 1960 s still remains an issue, which has not been researched in full and diagnosed as regards its impact combined with the ideology and the film industry. Because of the political situation at the time when it was implemented (the socialist system) the works were marked with a certain, top-imposed manner of interpretation. Accounting for the political changes in Poland after 1956, democratisation of the country became an official propaganda tool. Because of its international nature, democratisation, on one hand,
[9] J. Płażewski, Gra, miłość ma lat dwanaście czyli subiektywizm reżysera, "Kino" 1969, no. 4, p. 11.
[10] J. Jacoby, Film jako cybernetyczny przekaz informacji, "Kino" 1968, no. 3, p. 44. 


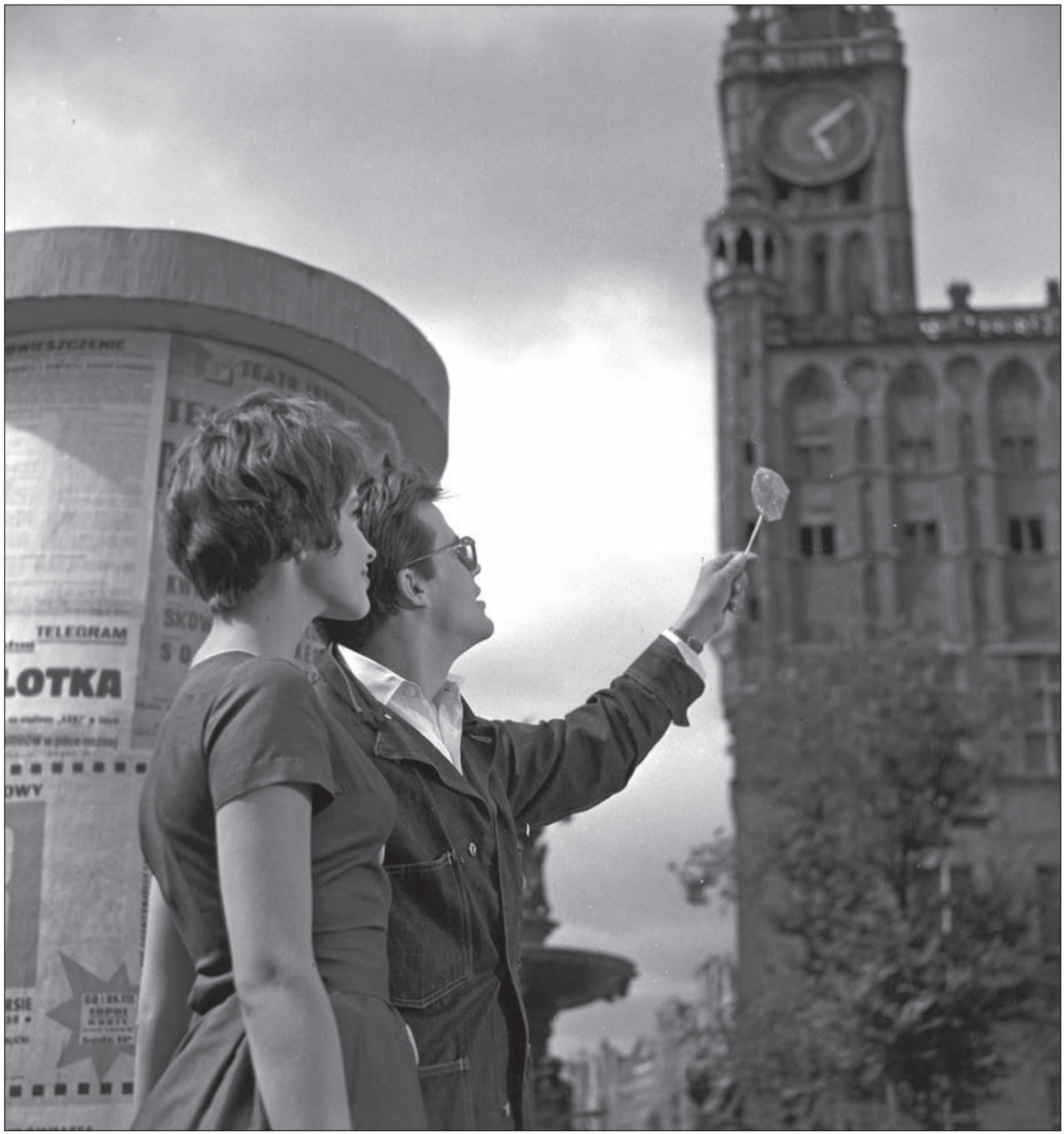

served as a link to western architecture, and, on the other hand, its internal impact focused on the use of the spatial and visual assets as a tool of the propaganda of success to present a positive image of the system to the citizens in Poland and also to foreigners.

The image of modern architecture and the city/town in Polish feature films of the times was focused on only presenting is positive spatial, visual and economic aspects. The feature film in the 196os, as a means of public media, became an ideal medium to show the modernity in Poland epitomised by new, modern buildings. The feature films of this period constitute ideal research material, representing and encapsulating the atmosphere of the times seen through the perspective of modernity recorded in film shots.
Il. 2. Main characters of the film entitled Do widzenia, do jutra [See You Tomorrow] against the background of the reconstructed Old Town in Gdańsk. 1-F-2111-83 
In this case, I must partly agree with the statement of Alicja Helman referring to the manner in which Polish film directors presented the reality of the 1960s: "Because our creative artists cannot synthesise the contemporary times or they can but do so only too rarely".[11] Of course, this synthesis of contemporary times perceived by a reviewer in the late 196os mainly referred to the psychological layer of Polish film. From the viewpoint of research into the history of architecture and urban planning of the time, the past and previous times were properly captured. Being a historical source, film may serve as perfect research material, especially in the area of architecture and urban planning. It may also be deemed as a source of documentation pertaining to the architectural activities then undertaken in Poland.

A still, 2-D picture of the architecture of the time published in a magazine or in a book is a valuable source of knowledge; however, a 3-D motion picture provides a totally different perspective of perception. It must be added, here, that as early as in the 1930s, Le Corbusier, the great architect of modernism, recorded his work in films. By doing this, he attempted to present the multidimensional image of this work.. A certain drawback of such a presentation was the author's imposed vision of the modern work seen from one perspective only.

Feature film as research material into the Polish urban planning and architecture of the $1960 \mathrm{~s}$
[11] A. Helman, Wymiar naszych spraw, "Kino" 1968, no. 7, p. 6.
Polish urban planning and architecture of the post-war period has been a frequent topic of research works and scientific theses in recent decades. Architectural historians try to work out an unambiguous diagnosis of that period from the contemporary point of view. Respective periods of architectural activities after 1945 are typically divided into periods corresponding to the historical periods. Thus, in the case here, the history of Polish post-war architecture and urban planning has been divided into the period of the reconstruction of Poland spanning from 1945 to 1956 and the period of 'small stabilisation' and the return to modernism in the years 1956-1968. Another period, from 1968 to 1980 , was the period of the political and architectural transformations brought about by social movements in order to produce a more democratic system in Poland. The last period within the framework of the research, which covered the years 1980-1989, was the period when the aforesaid creative opinions needed to face the difficult reality of the crisis of the Polish People's Republic in decline.

From the viewpoint of today's research, the period from 1956 to 1968 was the most interesting and prolific in the history of the postwar architecture in Poland. Another attempt to transform Poland into a more democratic country, after the years of the Stalinist terror, resulted in a burst of new ideas and concepts in the field of architecture and urban planning. Many of the creative minds of the time referred to the achievements of post-war modernism and similar movements; however, the distinguishing feature of their works was the social, political, 
economic and creative context of Poland in the 1960s. Receptiveness to new trends enabled many to create outstanding works, whose spatial and ideological quality is comparable to the artistic achievements in other European countries.

In my opinion, the film image is a valuable element of research material for an architectural historian, which may supplement the history of a particular architectural or urban planning work in many instances. To confirm the conclusions in this respect, I would quote the words of Alicja Helman "Making a film in a contemporary setting, you become either the chronicler of the everyday routine [...] or a sui generis bard, a man of knowledge ahead of the times he lives in, generalising and systematising the processes and development routes".[12] In my opinion, these words accurately reflect the intentions that guided the considerations here. For the architectural historian in Poland, the feature film has become a meaningful research element, which can broaden, and in some cases even verify, the available knowledge on the history of Polish architecture in the most recent period. The feature film, showing daily life, inherently diagnosed the multi-layered reality. Urban planning and architecture were components of this reality. The considerations in this article have focused on the feature film. One cannot, however, forget about the role other genres played in the recording of the image of modern architecture and urban planning, such as the documentary or educational film. Both of these film genres contain motion pictures worth researching in more detail.

The examples of such images documenting the achievements of modernism in European countries, which, for political and cultural reasons, appealed to the people in Poland in the period subject to analysis here, shall definitely include the films of Mieczysław Wiesiołek focused on modern French architecture[13] of 1956 and modern Italian architecture[14] of 1958. These images were to familiarise Polish viewers, not just architects, with the achievements of modern architectural trends. In my opinion, these films have become a valuable source of knowledge about contemporary European modernism.

Educational films, made e.g. in Wytwórnia Filmów Oświatowych [Educational Film Studio] in Łódź, can, in my view, serve as another path of research focused on historical as well as on modern architecture. An extensive catalogue of such films includes both the films focused on the historical as well as on the modern architecture in Poland. Some films in the studio library are clearly dedicated to the image of the Polish towns. One such film is entitled Poznan - the city of commerce and industry directed by Wiesław Drymer in 1966, where he recorded the image of Poznan as an example of a city which, on the one hand, is modern and international (because of the International Fairs held there) and, on the other hand, old and historical. This film shows a number

[12] Ibidem, p. 6.

[13] M. Wiesiołek, Contemporary French architecture, made in 1956.
[14] Idem, Notatki o nowej architekturze Włoch, made in 1958. 
of shots of the central area; where in the 196os the following examples of modern architecture could be identified: Centralny Dom Towarowy [Central Department Store] by Marek Leykam, dating back to 19481954, or the modern building of the 'Merkury' hotel by Jan Cieśliński, Jan Węcławski and Henryk Grochulski of 1964. Over the years, these two buildings have become architectural icons of the city. The former, after a successful modernisation between 2011-2012, continues to attract the eyes of inhabitants with its old splendour, modern building block and interesting architectural solutions such as the internal staircase with its gentle structure of the stairs lined with glass tiles. The latter, after a successful 'face-lift' on its façade in the middle of the 1990s, has lost its avant-garde appearance.

\section{Conclusions}

B I B L I O G R A P H Y

Research on the architecture and urban planning of the 1960 s must include an analysis of the motion pictures of the times. Numerous articles concerning urban planning and architectural works published in such magazines as "Architektura" [Architecture] and "Miasto" [City] enable us to follow the way modern design tendencies developed. From the point of view of the architectural historian, film may be deemed a valuable source of knowledge on iconic achievements, a source of supplementary archive and photographic materials. As mentioned before, a natural feature of urban planning or an architectural work is, on the one hand, its stability in the urban space and, on the other hand, its natural tendency to have its space used. A still image of architecture, frozen in a photograph, drawing or a plan, is sometimes insufficient to represent all the assets of the facility, which can be revealed in recorded film. Summing up my considerations so far, I would quote the following statement: "It may happen that photography and film gain the status of a document by pure coincidence, especially when, in the background of the most important foreground, they happen to record something, which over the years gains importance, much greater than originally assumed by the author of the shot." [15]

Faryna-Paszkiewicz H., Geometria wyobraźni. Szkice o architekturze dwudziestolecia międzywojennego, Gdańsk 2003

Helman A., Wymiar naszych spraw, „Kino” 1968, no. 7, pp. 2-11

Jacoby J., Film jako cybernetyczny przekaz informacji, „Kino” 1968, no. 3, pp. 41-46

Kotarbiński A., O ideowości i ideologii w architekturze i urbanistyce, Warszawa, 1985

Płażewski J., Gra, miłość ma lat dwanaście czyli subiektywizm reżysera, „Kino” 1969, no. 4 , pp. 5-11

[15] H. Faryna-Paszkiewicz, Geometria wyobraźni. Szkice o architekturze dwudziestolecia międzywojennego, Gdańsk 2003, p. 56. 